\title{
Penggunaan Media Video Berbantuan LKPD Untuk Meningkatkan Hasil Belajar Siswa Materi Kesetimbangan Kimia Kelas XI MIPA Di SMA Negeri 2 Palangka Raya
}

\author{
Rini Sundari", Suandi Sidauruk, Abdul Hadjranul Fatah \\ Program Studi Magister Pendidikan Kimia Program Pascasarjana, \\ Universitas Palangka Raya, Kampus UPR Tunjung Nyaho, Jl. Yos Sudarso, \\ Palangka Raya, Indonesia, 73111 \\ *Email: kimiasundari@gmail.com
}

Diterima: 22 Juni 2021; Disetujui: 24 Juni 2021; Diterbitkan: 26 Juni 2021

\begin{abstract}
ABSTRAK
Penelitian ini bertujuan untuk mengetahui pengaruh penggunaan media video berbantuan LKPD terhadap peningkatan hasil belajar siswa pada materi kesetimbangan kimia kelas XI MIPA di SMAN 2 Palangka Raya. Penelitian dilaksanakan di SMAN 2 Palangka Raya. Penelitian melibatkan 27 siswa kelas XI MIPA 6 SMAN 2 Palangka Raya tahun pelajaran 2020/2021. Instrumen yang digunakan yaitu (1) soal tes pemahaman konsep kesetimbangan kimia (TPK3) yang terdiri dari soal TPK3 pra media video berbantuan LKPD kesetimbangan kimia (TPK3 pra MVidLKPD) dan TPK3 pasca MVidLKPD; dan (2) instrumen penelusuran kemampuan memperoleh konsep kesetimbangan kimia berupa video pembelajaran dan Lembar Kerja Peserta Didik - Kesetimbangan Kimia (LKPDK2) yang diberikan saat pelaksanaan pembelajaran menggunakan media video berbantuan LKPD. Data dalam penelitian ini antara lain data hasil belajar kesetimbangan kimia, data penelusuran kemampuan memperoleh konsep kesetimbangan kimia, dan data penyebab kesalahan menjawab soal. Data dikumpulkan melalui beberapa tahap yaitu tes sebelum pembelajaran (TPK3 pra MVidLKPD), pelaksanaan pembelajaran menggunakan media video berbantuan LKPD, tes sesudah pembelajaran (TPK3 pasca MVidLKPD), dan wawancara. Wawancara dilakukan untuk memeriksa ulang informasi yang diberikan oleh hasil TPK3 pasca MPI-K2, untuk menemukan penyebab kesalahan siswa dalam menjawab soal, sehingga dapat disimpulkan pengaruh penggunaan MPI-K2 terhadap hasil belajar siswa. Data hasil belajar kesetimbangan kimia dianalisis dengan menghitung nilai berdasarkan skor perolehan setiap siswa, dengan memberikan skor pada setiap butir soal jika jawaban benar diberi skor 1 dan jawaban salah diberi skor 0 . Hasil penelitian menunjukkan bahwa penggunaan media video berbantuan LKPD dapat meningkatkan hasil belajar siswa yang ditunjukkan dari nilai siswa setelah mengikuti pembelajaran melampaui KKM yang telah ditetapkan oleh sekolah yaitu di atas 78 .
\end{abstract}

Kata Kunci: Kesetimbangan Kimia, LKPD, Media, Video. 


\section{PENDAHULUAN}

Pendidikan merupakan salah satu hal yang sangat dibutuhkan manusia, tanpa pendidikan manusia akan mengalami kesulitan untuk berkembang dan kemudian terbelakang. Pendidikan membuat siswa untuk memperoleh kesempatan, harapan, serta pengetahuan yang dapat mengantarkannya menuju kehidupan yang lebih baik (Sani, 2015). Perkembangan kurikulum menuntut siswa dalam proses pembelajaran untuk bersikap aktif, kreatif, dan inovatif. Hal ini dapat terwujud dengan cara menempatkan siswa sebagai objek pendidikan. Menurut Suyanto \& Jihad (2013) peran guru diantaranya sebagai pembimbing siswa dalam pembelajaran, fasilitator di kelas, penyedia lingkungan belajar yang baik dan manajer (yang mengatur proses pembelajaran). Seorang guru yang profesional dituntut untuk dapat menampilkan keahlian di depan kelas dengan landasan pengetahuan yang kuat. Salah satu komponen keahlian itu adalah kemampuan untuk menyampaikan pelajaran kepada siswa. Guru harus menguasai materi, metode, media, dan mampu merencanakan kemudian mengembangkan kegiatan pembelajarannnya, serta mampu menerapkan kurikulum dan metode mengajar secara inovatif.

Paulo Freire dalam Prastowo (2014) pernah melontarkan sebuah pemikiran bahwa pendidikan harus berorientasi kepada proses pengenalan pengetahuan yang bersifat objektif dan subjektif. Usaha mentransfer ilmu pengetahuan, pengalaman dan gagasan guru kepada siswa seringkali tidaklah mudah. Kelancaran interaksi ini sangat bergantung dengan sejauh mana kedua belah pihak mampu membangun komunikasi efektif. Namun apabila komunikasi tersebut menimbulkan kebingungan atau salah pengertian dan salah konsep maka tujuan dari proses pembelajaran menjadi sulit untuk dicapai. Guru harus menyiapkan sebuah perantara yang dapat berfungsi sebagai penyalur pesan, merangsang pikiran, perasaan dan kemauan siswa untuk memperlancar pencapaian tujuan pelaksanaan pendidikan. Media perantara yang dimaksud tidak lain adalah media pembelajaran.

Media pembelajaran sangat diperlukan untuk membimbing atau memberikan arahan kepada siswa dalam menemukan konsep serta prinsip dari suatu materi dalam pembelajaran. Media pembelajaran yang digunakan dapat mempengaruhi berhasil tidaknya kegiatan pembelajaran. Media pembelajaran dapat digunakan guru sebagai sarana untuk dapat menyampaikan materi pelajaran agar lebih menarik, tidak monoton, disenangi siswa, dan yang paling penting dapat meningkatkan semangat siswa dalam belajar. Media pembelajaran dapat dijadikan sebagai jembatan bagi siswa dalam mengkonstruk suatu konsep agar dihasilkan konsep yang kuat melekat diingatan siswa. Media pembelajaran yang sudah mulai dikenal saat ini salah satunya adalah video pembelajaran. Video pembelajaran mulai digunakan dalam pembelajaran, karena disamping menarik, media ini juga memudahkan siswa dalam mempelajari materi. Video 
pembelajaran juga dapat dikombinasikan dengan memberikan panduan belajar kepada siswa, berupa lembar kerja siswa yang sekarang disebut lembar kerja peserta didik yang disngkat LKPD. Lembar kerja peserta didik diberikan agar siswa lebih tertuntun dalam belajar, siswa tidak hanya menonton dan menyimak video saja tetapi juga menjawab pertanyaan-pertanyaan dalam LKPD. Siswa menjawab pertanyaan dalam LKPD diharapkan proses membangun konsep dalam pikirannya lebih terarah, sehingga pemahaman konsep yang baik dan utuh dapat diperoleh siswa.

Salah satu teori belajar yang melandasi munculnya inovasi dalam pembelajaran adalah teori belajar konstruktivisme. Prastowo (2014) menyatakan bahwa siswa mengkontruksi pengetahuannya melalui interaksi dengan objek, fenomena, pengalaman, dan lingkungannya yang harus diinterprestasikan sendiri oleh masing-masing siswa. Menurut Yaumi (2018) dalam pembelajaran konstruktivisme peserta didik mencoba membangun makna dari setiap pengalaman yang mereka lakukan. Peran media dan teknologi dalam pembelajaran konstruktivisme yaitu memfasilitasi terbentuknya interaksi, khususnya menyediakan lingkungan yang nyaman untuk siswa memaknai materi yang akan diajarkan. Menurut teori konstruktivisme, hal yang paling penting dalam pembelajaran adalah bahwa guru tidak hanya memberikan pengetahuan kepada siswa. Siswa harus membangun sendiri pengetahuan dalam pikirannya, guru hanya memberikan anak tangga yang dapat membawa siswa ke pemahaman yang ingin dicapai. Salah satu yang dapat diberikan guru adalah dengan memberikan media pembelajaran yang dapat membantu siswa membangun sendiri pengetahuan dalam pikirannya.

Kimia sebagai salah satu cabang sains yang juga menjadi mata pelajaran di Sekolah Menengah Atas (SMA) memiliki banyak konsep abstrak dan teoritis sehingga membutuhkan tingkat pemahaman siswa yang tinggi karena pokok bahasan dalam ilmu kimia yang bersifat kompleks. Kesetimbangan kimia merupakan salah satu materi pokok yang diajarkan pada kelas XI semester ganjil pada jenjang SMA/MA. Banyak kesulitan dan miskonsepsi yang dialami peserta didik dalam memahami konsep kesetimbangan kimia. Hasil penelitian Adawiyah (2017) menunjukkan adanya penyebab siswa mengalami kesalahan konsep kesetimbangan kimia antara lain penguasaan bahasa yang kurang, pemahaman terhadap materi yang kurang baik, daya ingat yang lemah serta minimnya sumber atau bahan belajar. Kesalahan konsep siswa pada materi kesetimbangan kimia antara lain: 1) kesalahan menafsirkan istilah-istilah kimia sebesar 5,48\%; 2) kesalahan menafsirkan konsep $(43,43 \%)$ yaitu salah menentukan definisi kesetimbangan kimia, menentukan rumus atau simbol tetapan kesetimbangan kimia; dan 3) kesalahan menafsirkan prinsip (16,42\%) yaitu prinsip Le Chatelier dan katalis. Sejalan dengan itu, Seliwati (2017) mendeskripsikan bahwa siswasiswi SMA di kota Palangka Raya mengalami kesulitan dalam konseptual dan prosedural (1) kesetimbangan dinamis; (2) pengaruh perubahan suhu terhadap 
pergeseran kesetimbangan (3) Pengaruh perubahan konsentrasi terhadap pergeseran kesetimbangan;(4) Pengaruh perubahan volume dan tekanan pada pergeseran kesetimbangan. Penyebab kesulitan adalah siswa tidak mengerti konsep yang bersifat makrokopis dan mikrokopis.

Penelitian Indriani (2017) menunjukkan bahwa kesulitan yang dialami peserta didik yaitu pada konsep kesetimbangan dinamis, konstanta kesetimbangan, dan faktor-faktor yang mempengaruhi pergeseran kesetimbangan. Monita (2016) dalam penelitiannya mendeskripsikan miskonsepsi siswa pada konsep kesetimbangan kimia antara lain pada konsep kesetimbangan dinamis, konsep kesetimbangan homogen dan heterogen, konsep tetapan kesetimbangan, konsep hubungan kuantitatif antar komponen dalam reaksi kesetimbangan, konsep pergeseran kesetimbangan, dan konsep kesetimbangan kimia dalam proses industri. Penelitian Usu (2019) juga menunjukkan bahwa siswa mengalami miskonsepsi konsep kesetimbangan kimia. Miskonsepsi yang dialami siswa terjadi pada subkonsep kesetimbangan dinamis (26,9\%), subkonsep pergeseran kesetimbangan kimia (40\%), subkonsep tetapan kesetimbangan kimia (49,3\%) dan subkonsep kesetimbangan kimia dalam suatu industri (31,6\%). Dari hasil penelitian dapat disimpulkan bahwa miskonsepsi tertinggi pada subkonsep tetapan kesetimbangan kimia, sedangkan untuk persentase terendah pada subkonsep kesetimbangan dinamis. Miskonsepsi teridentifikasi disetiap sub konsep pada konsep kesetimbangan kimia dengan rata-rata sebesar 37\%.

Proses pembelajaran pada pandemi Covid-19 yang mengharuskan guru melakukan Pembelajaran Jarak Jauh (PJJ) atau sering disebut pembelajaran daring juga menjadi tantangan bagi guru untuk dapat melakukan inovasi pembelajaran. Inovasi pembelajaran yang dilakukan oleh guru dapat mewujudkan pembelajaran bermakna yang diharapkan dapat meningkatkan pemahaman konsep peserta didik khususnya konsep kesetimbangan kimia. Maka dari itu, peneliti beranggapan bahwa pengunaan media video berbantuan LKPD diharapkan bisa menjadi solusi untuk permasalahan tersebut. Media video berbantuan LKPD dalam penelitian ini berupa video pembelajaran yang diberikan tambahan panduan belajar berupa Lembar Kerja Peserta Didik (LKPD) yang akan mempermudah siswa dalam memahami konsep kesetimbangan kimia. Media video berbantuan LKPD dianggap sebagai pilihan yang tepat digunakan dalam pembelajaran karena siswa tidak hanya dituntut untuk mendengar atau melihat video saja, tetapi juga menulis konsep-konsep yang sudah dirancang dalam LKPD. Media video berbantuan LKPD ini diharapkan bisa menunjang semua gaya belajar siswa, antara lain gaya belajar auditori, visual dan kinestetik. Gaya belajar auditori dan visual melalui mengamati video, sedangkan gaya belajar kinestetik melalui menulis LKPD. Selain itu proses belajar seperti yang diinginkan dalam teori belajar konstruktivisme juga akan mudah dilaksanakan dengan penggunaan media video berbantuan LKPD ini. Melalui media video berbantuan LKPD, siswa akan lebih mudah memahami konsep karena siswa 
dimungkinkan membangun sendiri konsep dalam pikirannya. Pemahaman terhadap konsep yang baik akan membuat siswa memperoleh hasil belajar yang baik pula.

Menurut Majid (2014), salah satu keberhasilan proses belajar mengajar dapat dilihat dari hasil belajar yang dicapai oleh siswa. Hasil belajar siswa merupakan perubahan tingkah laku setelah melalui proses belajar mengajar. Hasil belajar merupakan tingkat perkembangan mental yang lebih baik bila membandingkannya dengan pengetahuan siswa sebelum mengikuti pembelajaran. Woordworth dalam Majid (2014) juga mengatakan bahwa hasil belajar merupakan kemampuan aktual yang diukur secara langsung, yang dengannya kita akan mengetahui seberapa jauh tujuan pembelajaran telah tercapai. Penilaian hasil belajar siswa pada Kurikulum 2013 menggunakan suatu kriteria yang telah ditetapkan oleh satuan pendidikan. Kriteria yang dimaksud yaitu Kriteria Ketuntasan Minimum (biasa disingkat KKM). KKM merupakan acuan yang digunakan guru untuk menilai kesesuaian kompetensi yang diperoleh siswa dalam pembelajaran dengan Kompetensi Dasar (KD) yang telah ditetapkan. Nilai KKM ditetapkan oleh sekolah dengan memperhatikan karakteristik siswa, karakteristik mata pelajaran, dan kondisi/daya dukung sekolah.

Tujuan penelitian ini adalah untuk mengetahui pengaruh penggunaan media video berbantuan LKPD terhadap hasil belajar siswa pada materi kesetimbangan kimia kelas XI MIPA di SMAN 2 Palangka Raya

\section{METODOLOGI PENELITIAN}

Jenis penelitian yang digunakan yaitu penelitian deskriptif. Penelitian deskriptif adalah penelitian yang berusaha mendeskripsikan suatu gejala, peristiwa, kejadian yang terjadi saat sekarang (Trianto, 2011). Penelitian ini mendeskripsikan bagaimana siswa membangun konsep kesetimbangan kimia melalui media video berbantuan LKPD (MVidLKPD) yang digunakan. Hasil akhir dari penelitian ini adalah peningkatan hasil belajar siswa setelah melalui proses pembelajaran menggunakan media video berbantuan LKPD.

Penelitian dilaksanakan di SMAN 2 Palangka Raya tahun pelajaran 2020/2021 mulai bulan Agustus 2020 - Mei 2021. Guna kesesuaian dengan materi pelajaran yang diteliti, maka kelas yang diambil sebagai subjek penelitian yaitu kelas XI MIPA.

Penelitian ini meliputi tiga tahap yaitu (1) tahap penyusunan media meliputi penentuan materi, penentuan video yang sesuai dengan materi dan menguji keterbacaan media, (2) tahap persiapan pengambilan data meliputi penyusunan instrumen, validasi instrumen, perizinan dan pengambilan data, (3) tahap pelaksanaan pembelajaran menggunakan media video berbantuan LKPD.

Data pada penelitian ini terdiri dari 3 jenis, yaitu data hasil belajar kesetimbangan kimia, data penelusuran kemampuan memperoleh konsep kesetimbangan kimia, dan data penyebab kesalahan menjawab soal. Data hasil 
belajar kesetimbangan kimia dijaring dengan lembar Tes Pemahaman Konsep Kesetimbangan Kimia (TPK3) berupa tes bentuk pilihan ganda sebanyak 15 soal. Tes diberikan kepada 27 orang siswa yang akan mengikuti pembelajaran menggunakan media video berbantuan LKPD. Data hasil TPK3 terdiri dari data hasil TPK3 pra MVidLKPD dan TPK3 pasca MVidLKPD. Soal TPK3 pra MVidLKPD dan TPK3 pasca MVidLKPD dibuat dengan redaksi soal yang berbeda namun tetap mengukur kompetensi yang sama. MVidLKPD adalah kepanjangan dari Media Video Berbantuan LKPD. Indikator yang akan dicapai dalam penelitian ini dapat dilihat pada Tabel 1. Data penelusuran kemampuan memperoleh konsep kesetimbangan kimia dijaring melalui kegiatan saat pelaksanaan pembelajaran menggunakan media video berbantuan LKPD yaitu berupa Lembar Kerja Peserta Didik-Kesetimbangan Kimia (LKPD-K2) yang diisi siswa saat mengamati video atau setelah tayangan video pada setiap konsep yang diberikan saat pelaksanaan pembelajaran menggunakan media video berbantuan LKPD. Data penyebab kesalahan menjawab soal diperoleh dari wawancara/tanya jawab yang dilakukan kepada siswa yang menjawab salah pada TPK3 pasca MVidLKPD. Wawancara dilakukan untuk memeriksa ulang informasi yang diberikan oleh hasil TPK3 pasca MVidLKPD, untuk menemukan penyebab kesalahan siswa dalam menjawab soal, sehingga dapat disimpulkan pengaruh atau hubungan penggunaan media video berbantuan LKPD terhadap peningkatan hasil belajar siswa.

Tabel 1. Indikator Instrumen

\begin{tabular}{lll}
\hline \multicolumn{1}{c}{ Kompetensi Dasar } & \multicolumn{2}{c}{ Indikator Pencapaian Kompetensi } \\
\hline 3.6 Menjelaskan reaksi & 1. Siswa dapat membedakan reaksi \\
kesetimbangan di dalam & irreversible dan reversible. \\
hubungan antara pereaksi & 2. Siswa dapat menjelaskan \\
dan hasil reaksi & kesetimbangan dinamis \\
3. Siswa dapat merumuskan tetapan \\
kesetimbangan berdasarkan konsentrasi \\
\\
$\left(K_{\mathrm{c}}\right)$ berdasarkan persamaan reaksi \\
kesetimbangan \\
4. Siswa dapat merumuskan tetapan \\
kesetimbangan berdasarkan tekanan \\
$\left(K_{\mathrm{p}}\right)$ berdasarkan persamaan reaksi \\
kesetimbangan
\end{tabular}

5. Siswa dapat menentukan kesetimbangan homogen dalam suatu reaksi kesetimbangan

6. Siswa dapat menentukan kesetimbangan heterogen dalam suatu reaksi kesetimbangan 


\begin{tabular}{|c|c|}
\hline Kompetensi Dasar & Indikator Pencapaian Kompetensi \\
\hline & $\begin{array}{l}\text { 7. Siswa dapat menentukan perubahan } \\
\text { konsentrasi pada reaktan dan produk } \\
\text { berdasarkan } \text { grafik }\end{array}$ \\
\hline & $\begin{array}{l}\text { konsentrasi dan waktu } \\
\text { 8. Siswa dapat menghitung } K_{\mathrm{c}} \text { berdasarkan } \\
\text { data konsentrasi zat-zat yang terlibat } \\
\text { dalam reaksi kesetimbangan }\end{array}$ \\
\hline & 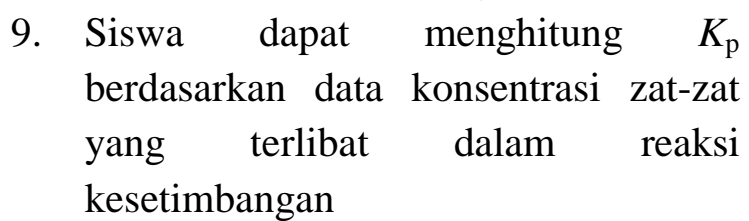 \\
\hline & $\begin{array}{l}\text { 10. Siswa dapat menentukan hubungan } K_{c} \\
\text { dan } K_{p} \text { suatu reaksi kesetimbangan. }\end{array}$ \\
\hline
\end{tabular}

Data yang dianalisis pada penelitian ini berupa data pemahaman konsep siswa mengenai kesetimbangan kimia yang meliputi data hasil belajar, data penelusuran kemampuan memperoleh konsep, dan data penyebab kesalahan menjawab soal.

Data hasil belajar kesetimbangan kimia berupa data hasil TPK3 pra MVidLKPD dan data hasil TPK3 pasca MVidLKPD. Data berupa hasil tes dilakukan pemberian skor pada setiap butir soal. Setiap butir soal yang dijawab benar oleh siswa diberi skor 1, sedangkan butir soal yang dijawab salah diberi skor 0. Data hasil belajar dianalisis dengan menghitung nilai siswa berdasarkan skor perolehan setiap siswa, dengan rumus:

$$
\text { Nilai siswa }=\frac{\sum \text { skor benar setiap siswa }}{\text { skor maksimal }} \times 100
$$

Presentase skor benar dihitung dengan persamaan berikut.

$$
\% \text { skor benar }=\frac{\sum \text { skor siswa yang menjawab benar }}{N \times \text { skor maksimal }} \times 100 \%
$$

dengan $\mathrm{N}=$ jumlah siswa

Persentase kesulitan dihitung dengan persamaan:

$$
\% \text { kesulitan siswa }=100 \%-\% \text { skor benar }
$$

Data dideskripsikan dengan membandingkan perubahan hasil belajar siswa sebelum diberikan perlakuan dengan sesudah diberikan perlakuan. Sedangkan data penelusuran kemampuan memperoleh konsep berupa hasil jawaban LKPD- 
K2 siswa digunakan untuk menjelaskan pengaruh penggunaan media video berbantuan LKPD dalam pembelajaran terhadap pemahaman konsep kesetimbangan kimia siswa. Data penyebab kesalahan menjawab soal yang diperoleh melalui wawancara digunakan untuk memperkuat dugaan peneliti terhadap penyebab kesalahan konsep siswa pada beberapa konsep kesetimbangan kimia. Data hasil wawancara juga digunakan untuk menjelaskan pengaruh penggunaan media video berbantuan LKPD dalam pembelajaran terhadap peningkatan hasil belajar siswa pada materi kesetimbangan kimia.

\section{HASIL PENELITIAN DAN PEMBAHASAN}

\section{Hasil Penelitian}

Hasil belajar siswa pada materi kesetimbangan kimia setelah penggunaan media video berbantuan LKPD dapat dikatakan meningkat. Hal ini dapat dilihat dari skor hasil TPK3 pasca MVidLKPD yaitu semua siswa tuntas dengan nilai melampaui Kriteria Ketuntasan Minimum (KKM) yang telah ditentukan sekolah yaitu 78. Grafik nilai siswa berdasarkan skor hasil TPK3 pra dan pasca MVidLKPD dapat dilihat pada Gambar 1.

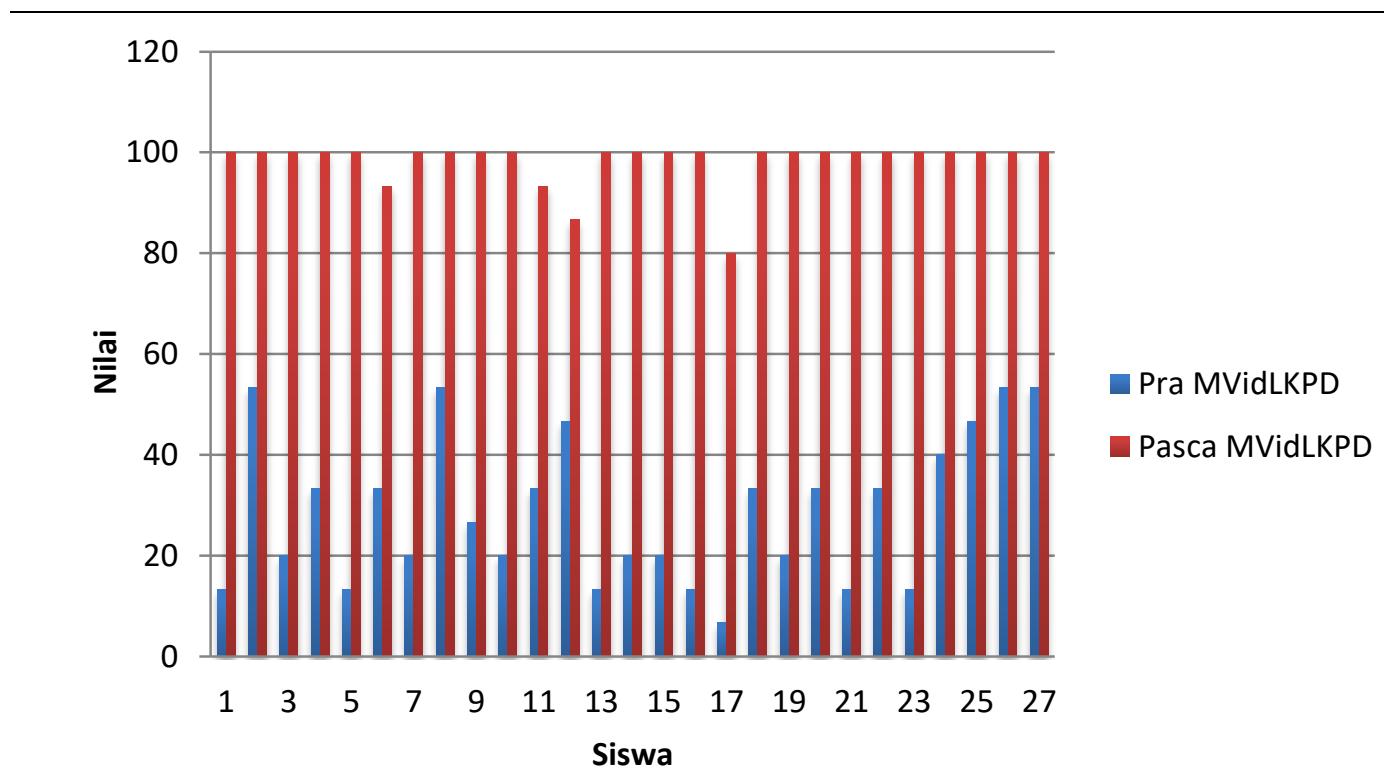

Gambar 1. Grafik Nilai Siswa pada Pra dan Pasca MVidLKPD

Gambar 1 menunjukkan bahwa nilai semua siswa pada saat sebelum diberikan perlakuan yaitu pra MVidLKPD masih dibawah KKM. Nilai siswa setelah pembelajaran menggunakan media video berbantuan LKPD (pasca MVidLKPD) mengalami peningkatan nilai yang signifikan dan semua nilai siswa melampaui KKM.

Jawaban siswa pada TPK3, selain menunjukkan adanya peningkatan hasil belajar, tentu saja diharapkan dapat menunjukkan perubahan pemahaman konsep 
kesetimbangan kimia siswa pada indikator pencapaian kompetensi yang telah disebutkan Tabel 1. Perubahan pemahaman konsep kesetimbangan kimia siswa pada pembelajaran menggunakan MVidLKPD untuk tiap indikator pencapaian kompetensi dan butir soal disajikan pada Tabel 2.

Tabel 2. Perubahan Pemahaman Konsep Siswa pada Pembelajaran Menggunakan MVidLKPD

\begin{tabular}{|c|c|c|c|c|}
\hline \multirow{2}{*}{$\begin{array}{c}\text { Indikator } \\
\text { Pencapaian } \\
\text { Kompetensi }\end{array}$} & \multirow{2}{*}{$\begin{array}{l}\text { Butir } \\
\text { Soal }\end{array}$} & \multirow{2}{*}{ Pemahaman Konsep } & \multicolumn{2}{|c|}{$\begin{array}{c}\text { Jumlah dan Persentase Siswa } \\
\text { yang Menjawab Benar }\end{array}$} \\
\hline & & & $\begin{array}{c}\text { Pra } \\
\text { MVidLKPD }\end{array}$ & $\begin{array}{c}\text { Pasca } \\
\text { MVidLKPD }\end{array}$ \\
\hline Indikator 1 & 1 & $\begin{array}{l}\text { Membedakan reaksi } \\
\text { irreversible dan } \\
\text { reversible }\end{array}$ & $15(55,5 \%)$ & $27(100 \%)$ \\
\hline Indikator 2 & 2 & $\begin{array}{l}\text { Menjelaskan } \\
\text { kesetimbangan dinamis. }\end{array}$ & $15(55,5 \%)$ & $27(100 \%)$ \\
\hline \multirow{2}{*}{ Indikator 3} & 3 & $\begin{array}{l}\text { Membuat rumusan } \\
\text { tetapan kesetimbangan } \\
\text { berdasarkan konsentrasi } \\
\left(K_{\mathrm{c}}\right) \text { untuk reaksi } \\
\text { kesetimbangan homogen }\end{array}$ & $10(37 \%)$ & $27(100 \%)$ \\
\hline & 4 & $\begin{array}{l}\text { Membuat rumusan } \\
\text { tetapan kesetimbangan } \\
\text { berdasarkan konsentrasi } \\
\left(K_{\mathrm{c}}\right) \text { untuk reaksi } \\
\text { kesetimbangan heterogen }\end{array}$ & $6(22 \%)$ & $27(100 \%)$ \\
\hline Indikator 4 & 5 & $\begin{array}{l}\text { Membuat rumusan } \\
\text { tetapan kesetimbangan } \\
\text { berdasarkan tekanan }\left(K_{\mathrm{p}}\right)\end{array}$ & $7(26 \%)$ & $25(93 \%)$ \\
\hline Indikator 5 & 6 & $\begin{array}{l}\text { Menentukan } \\
\text { kesetimbangan homogen } \\
\text { dalam suatu reaksi } \\
\text { kesetimbangan }\end{array}$ & $7(26 \%)$ & $27(100 \%)$ \\
\hline Indikator 6 & 7 & $\begin{array}{l}\text { Menentukan } \\
\text { kesetimbangan heterogen } \\
\text { dalam suatu reaksi } \\
\text { kesetimbangan }\end{array}$ & $9(33 \%)$ & $27(100 \%)$ \\
\hline Indikator 7 & 8 & $\begin{array}{l}\text { Menentukan perubahan } \\
\text { konsentrasi pada reaktan } \\
\text { dan produk berdasarkan } \\
\text { grafik hubungan } \\
\text { konsentrasi dan waktu }\end{array}$ & $5(19 \%)$ & $24(89 \%)$ \\
\hline
\end{tabular}




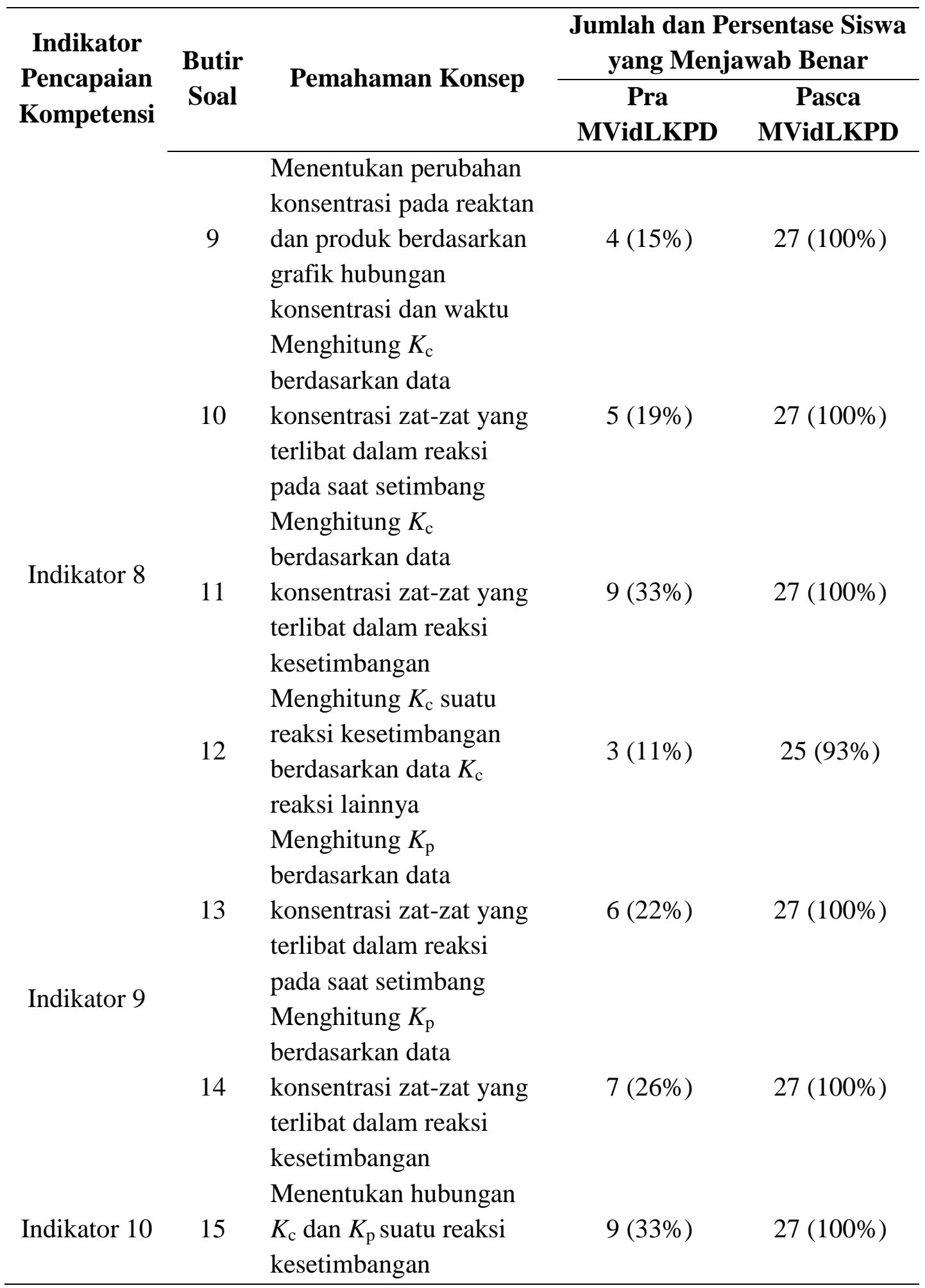

Berdasarkan Tabel 2 terlihat bahwa penggunaan MVidLKPD dalam pembelajaran dapat memberikan perubahan yang baik terhadap pemahaman konsep kesetimbangan kimia siswa. Siswa memperoleh pengetahuan tentang kesetimbangan kimia dalam pembelajaran menggunakan media video berbantuan LKPD. Proses membangun pemahaman tentang konsep kesetimbangan kimia 
diperoleh pada saat menyimak video kemudian menjawab pertanyaan pada LKPD. Beberapa siswa memahami konsep tidak cukup hanya dengan melihat dan mendengar video saja, maka dengan meenjawab LKPD diharapkan proses belajar menjadi lebih bermakna, penyimpanan konsep dalam memori siswa menjadi lebih maksimal.

Jawaban siswa terhadap Tes Pemahaman Konsep Kesetimbangan Kimia pasca MVidLKPD (TPK3 pasca MVidLKPD) menunjukkan bahwa pada beberapa indikator pencapaian kompetensi sebanyak $100 \%$ siswa dapat menjawab soal dengan benar. Hasil ini menunjukkan bahwa pembelajaran menggunakan media video berbantuan LKPD berpengaruh baik terhadap pemahaman konsep siswa. Konsep yang dimaksud antara lain membedakan reaksi reversible dan irreversible, kesetimbangan dinamis, membuat rumusan $K_{\mathrm{c}}$, kesetimbangan homogen dan heterogen, menghitung $K_{\mathrm{p}}$, serta menentukan hubungan $K_{\mathrm{c}}$ dan $K_{\mathrm{p}}$ suatu reaksi kesetimbangan. Beberapa konsep masih terdapat siswa yang menjawab salah, yaitu konsep tentang membuat rumusan $K_{\mathrm{p}}$, menentukan perubahan konsentrasi pada reaktan dan produk berdasarkan grafik hubungan konsentrasi dan waktu, serta konsep menghitung $K_{\mathrm{c}}$.

Jawaban siswa pada TPK3 pasca MVidLKPD mengenai pemahaman konsep tentang membuat rumusan tetapan kesetimbangan berdasarkan tekanan $\left(K_{\mathrm{p}}\right)$ menunjukkan sebanyak $7 \%$ siswa (2 orang siswa) masih salah menjawab soal tentang rumusan $K_{\mathrm{p}}$. Dua orang siswa ini kemudian ditelusuri jawaban LKPDK2nya. Jawaban LKPD-K2 menunjukkan bahwa siswa tersebut salah dalam

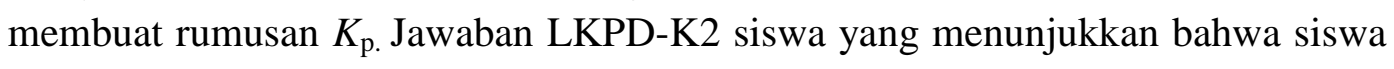
salah dalam memahami konsep membuat rumusan $K_{\mathrm{p}}$ dapat dilihat pada Gambar 2.

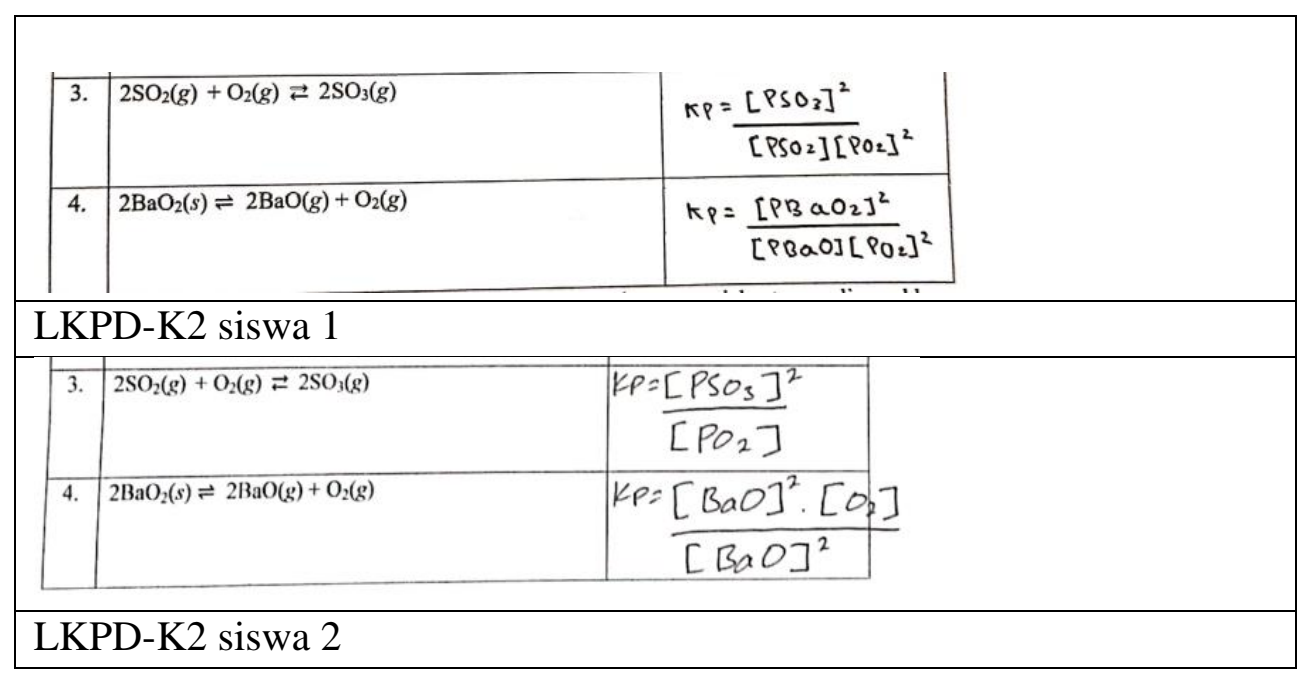

Gambar 2. Contoh Jawaban LKPD-K2 Siswa yang Salah dalam Membuat Rumusan Tetapan Kesetimbangan Berdasarkan Tekanan $\left(K_{\mathrm{p}}\right)$ 
Gambar 2 menunjukan siswa tidak memahami penulisan rumusan $K_{\mathrm{p}}$ untuk reaksi homogen berwujud gas bahwa semua zat yang terlibat dalam reaksi dimasukkan dalam rumusan $K_{\mathrm{p}}$. Siswa juga tidak memahami penulisan rumusan $K_{\mathrm{p}}$ untuk reaksi heterogen berwujud gas dan padat, bahwa zat yang berwujud padat tidak diperhitungkan dalam rumusan $K_{\mathrm{p}}$. Hasil wawancara menunjukkan bahwa ada dua penyebab kesalahan siswa yaitu (1) siswa merasa waktu yang diberikan terlalu singkat untuk mengisi LKPD yang mengakibatkan siswa terlambat mengerjakan soal sehingga terburu-buru dalam menjawab; dan (2) siswa tidak memahami tentang istilah koefisien reaksi yang mengakibatkan siswa salah dalam menjawab soal.

Jawaban siswa terhadap TPK3 pasca MVidLKPD mengenai konsep perubahan konsentrasi pada reaktan dan produk berdasarkan grafik hubungan konsentrasi dan waktu menunjukkan sebanyak $11 \%$ siswa (3 orang siswa) masih salah menjawab butir soal nomor 8 . Tiga orang siswa yang menjawab salah tersebut kemudian dilakukan penelusuran terhadap LKPD-K2 yang sudah dijawabnya. Jawaban LKPD-K2 menunjukkan siswa tersebut sudah benar dalam mengisi LKPD, khususnya dalam konsep perubahan konsentrasi pada reaktan dan produk berdasarkan grafik hubungan konsentrasi dan waktu. Hasil wawancara menunjukkan bahwa penyebab kesalahan siswa yaitu siswa terbalik memahami tentang istilah produk dan reaktan dalam reaksi kimia. Pada keadaan ini sebab kesalahan siswa adalah karena pengetahuan prasyarat siswa yang masih salah. Maka perbaikan selanjutnya adalah bahwa guru harus memperhatikan pengetahuan prasyarat siswa sehingga siswa tidak gagal dalam memahami pengetahuan yang baru. Penyusunan media pembelajaran dapat diperbaiki dengan menambahkan pengetahuan prasyarat pada awal pembelajaran.

Jawaban siswa terhadap TPK3 pasca MVidLKPD mengenai konsep menghitung $K_{\mathrm{c}}$ menunjukkan sebanyak $7 \%$ siswa (2 orang siswa) masih salah menjawab butir soal nomor 12. Jawaban LKPD-K2 menunjukkan siswa ada kesalahan saat menghitung $K_{\mathrm{c}}$ berdasarkan data $K_{\mathrm{c}}$ reaksi lainnya. Jawaban LKPDK2 siswa yang dimaksud dapat dilihat pada Gambar 3.

Gambar 3 menunjukan jawaban LKPD-K2 siswa yang masih ada kesalahan dalam menghitung $K_{\mathrm{c}}$ berdasarkan data $K_{\mathrm{c}}$ reaksi yang lain. Siswa salah dalam menentukan hubungan antar reaksi dan salah dalam operasi matematika. Hasil wawancara terhadap siswa diperoleh bahwa siswa salah dalam menjawab LKPD karena terburu-buru, siswa mengaku bahwa materi yang diberikan terlalu banyak mengakibatkan tidak mampu memahami materi tersebut. Siswa juga mengaku bahwa karena terlalu banyaknya reaksi dan angka menyebabkan kebingungan. Siswa tidak menguasai operasi matematika dengan baik. Berdasarkan hal tersebut maka untuk penelitian selanjutnya sebaiknya cakupan materi jangan terlalu banyak mengingat materi kesetimbangan kimia yang terlalu kompleks. 


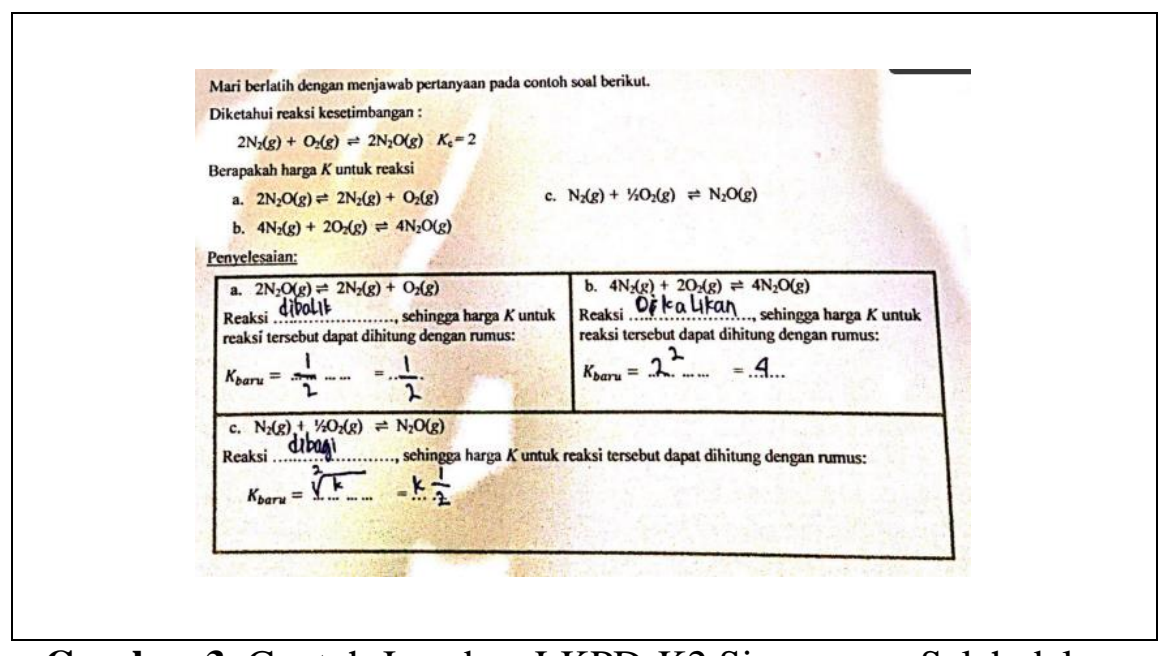

Gambar 3. Contoh Jawaban LKPD-K2 Siswa yang Salah dalam Menjawab Soal Menghitung $K_{\mathrm{c}}$

\section{Pembahasan}

Peningkatan hasil belajar siswa merupakan hasil yang diharapkan dalam proses pembelajaran. Nilai siswa setelah pembelajaran menggunakan MVidLKPD (pasca MVidLKPD) mengalami peningkatan, dimana nilai semua siswa telah melampaui KKM. Peningkatan nilai siswa ini menunjukkan adanya peningkatan hasil belajar siswa setelah diberikan perlakuan berupa penggunaan media video berbantuan LKPD dalam pembelajaran.

Penggunaan media video berbantuan LKPD seperti yang telah dilakukan peneliti, dapat mengarahkan siswa untuk membangun pengetahuannya secara mandiri seperti yang diharapkan dalam teori konstruktivisme. Menurut Nur dalam Trianto (2009), teori konstruktivisme merupakan teori belajar dimana siswa harus menemukan sendiri dan mentranformasikan pengetahuan yang diperolehnya dengan cara menghubungkan pengetahuan yang baru dengan pengetahuan yang telah diperoleh sebelumnya. Siswa yang dapat membangun sendiri pengetahuannya diharapkan dapat menghasilkan pemahaman konsep yang lebih baik. Proses membangun pengetahuan tersebut dapat diperoleh dengan menggunakan media video berbantuan LKPD dalam pembelajaran, khususnya dengan memanfaatkan video dan lembar kerja peserta didik. Hal ini sejalan dengan temuan Nurhayati (2014) mengenai pengaruh video-animasi terhadap hasil belajar siswa kelas XI SMAN 5 Pontianak pada materi kesetimbangan kimia yang menghasilkan pengaruh sebesar $27,34 \%$. Hal serupa juga diperoleh Virtayanti (2019) mengenai pengaruh lembar kerja siswa berorientasi keterampilan generik sains dengan model pembelajaran discovery learning terhadap pemahaman konsep kesetimbangan kimia menunjukkan ada pengaruh yang positif dan signifikan dari penggunaan LKS berorientasi KGS terhadap konsep kesetimbangan kimia siswa.

Hasil kedua penelitian di atas sejalan dengan hasil yang diperoleh peneliti. Penggunaan media pembelajaran dengan menggabungkan video dan lembar kerja 
peserta didik seperti yang telah dilakukan peneliti akan memberikan hasil yang lebih baik. Media pembelajaran yang memanfaatkan video dan lembar kerja peserta didik sekaligus dalam pembelajaran tentunya akan mewakili semua gaya belajar siswa yaitu gaya belajar audio, visual, dan kinestetik. Seperti yang diungkapkan Sanjaya (2012) bahwa salah satu manfaat penggunaan multimedia dalam proses pembelajaran dapat melayani perbedaan gaya belajar. Ada siswa yang lebih banyak menangkap materi pelajaran dengan menggunakan pendengaran (auditif). Ada juga siswa lebih banyak menangkap materi pelajaran dengan mengandalkan penglihatan (visual). Ada pula tipe siswa kinestetis yang cenderung menangkap materi pelajaran dengan cara melakukan. Melalui media video berbantuan LKPD yang digunakan peneliti dalam pembelajaran, menyimak video dapat mendukung gaya belajar audio dan visual, sedangkan mengisi lembar kerja peserta didik dapat mendukung berkembangnya konsep pada anak yang terbiasa dengan gaya belajar kinestetik.

Media video berbantuan merupakan media penyampai pesan agar siswa dapat memperoleh dan memahami konsep kesetimbangan kimia dengan baik. Tampilan video pada media video berbantuan LKPD dapat dibagi menjadi tiga bagian yaitu tampilan berupa narasi, tampilan berupa animasi, dan tampilan berupa simulasi pemahaman konsep. Tampilan video berupa narasi menjelaskan konsep-konsep dalam bentuk kalimat yang dijelaskan sedemikian rupa agar dapat membantu siswa memperoleh dan memahami konsep. Tampilan video berupa narasi membantu siswa memperoleh dan memahami konsep mengenai reaksi irreversible dan reversible, kesetimbangan homogen dan heterogen, serta grafik perubahan konsentrasi pada reaktan dan produk Tampilan video berupa animasi menjelaskan konsep-konsep dalam bentuk animasi molekul yang dapat mengantarkan siswa dalam memahami suatu konsep. Tampilan video berupa animasi membantu siswa memperoleh dan memahami konsep mengenai kesetimbangan dinamis. Tampilan video berupa simulasi pemahaman konsep menjelaskan cara mengaplikasikan suatu konsep pada suatu keadaan baru atau yang berhubungan dengan perhitungan kimia. Tampilan video berupa simulasi pemahaman konsep membantu siswa memperoleh dan memahami konsep mengenai rumusan $K_{\mathrm{c}}$, rumusan $K_{\mathrm{p}}$, menghitung $K_{\mathrm{c}}$, menghitung $K_{\mathrm{p}}$ serta hubungan $K_{\mathrm{c}}$ dan $K_{\mathrm{p}}$. Hal ini sejalan dengan penelitian Nurhayati (2014) yaitu video-animasi berpengaruh terhadap hasil belajar kesetimbangan kimia siswa dengan pengaruh sebesar $27,34 \%$.

Konsep kesetimbangan kimia dimana siswa masih mengalami kesulitan pada penelitian ini antara lain 1) merumuskan tetapan kesetimbangan berdasarkan tekanan $\left(K_{\mathrm{p}}\right)$; 2) menentukan perubahan konsentrasi pada reaktan dan produk berdasarkan grafik hubungan konsentrasi dan waktu; 3) menghitung $K_{\mathrm{c}}$ suatu reaksi kesetimbangan berdasarkan data $K_{\mathrm{c}}$ reaksi yang lain. Pada konsep merumuskan tetapan kesetimbangan berdasarkan tekanan $\left(K_{\mathrm{p}}\right)$, kesalahan siswa terjadi karena siswa tidak memahami penulisan rumusan $K_{\mathrm{p}}$ untuk reaksi 
heterogen berwujud gas dan padat, bahwa zat yang berwujud padat tidak diperhitungkan dalam rumusan $K_{\mathrm{p}}$. Hal ini serupa dengan temuan Adawiyah (2017) bahwa siswa mengalami kesalahan menafsirkan konsep yaitu zat yang berwujud padat diikutsertakan dalam rumus. Berdasarkan wawancara, diperoleh bahwa salah satu penyebab kesalahan siswa yaitu tidak memahami tentang istilah koefisien reaksi yang mengakibatkan siswa salah dalam menjawab soal. Hal ini juga serupa dengan temuan Indriani (2017) yaitu salah satu penyebab kesulitan siswa adalah siswa menuliskan persamaan konstanta kesetimbangan $(K)$ tanpa melibatkan koefisien reaksi.

Kesalahan yang disebabkan karena kurangnya pemahaman tentang istilah kimia juga terjadi pada konsep menentukan perubahan konsentrasi pada reaktan dan produk berdasarkan grafik hubungan konsentrasi dan waktu. Kesalahan siswa dalam menjawab soal pada konsep ini disebabkan siswa salah memahami tentang istilah produk dan reaktan dalam reaksi kimia. Hal serupa ditemukan oleh Oktaria (2012) yaitu salah satu penyebab miskonsepsi kesetimbangan kimia siswa adalah siswa terbalik dalam menggunakan istilah reaktan dan hasil reaksi. Hal ini sejalan dengan temuan Erdemir (2000) yaitu banyak siswa menunjukkan miskonsepsi dalam konsep kesetimbangan kimia dikarenakan konsepnya yang abstrak dan menggunakan istilah sulit dipahami siswa. Perbaikan selanjutnya yang dapat dilakukan guru antara lain harus memperkenalkan istilah-istilah kimia seperti koefisien reaksi, produk dan reaktan sampai tuntas. Sebelum memulai pembelajaran guru juga memperhatikan pengetahuan prasyarat yang harus dikuasai siswa sehingga siswa tidak gagal dalam memahami pengetahuan yang baru.

Konsep menghitung $K_{\mathrm{c}}$ suatu reaksi kesetimbangan berdasarkan data $K_{\mathrm{c}}$ reaksi yang lain menunjukkan siswa juga mengalami kesalahan. Berdasarkan hasil wawancara diketahui bahwa penyebab siswa salah dalam menjawab soal karena terlalu banyaknya reaksi dan angka yang menyebabkan kebingungan pada siswa. Ini salah satu sebab dari kurangnya kemampuan matematik atau tidak menguasai operasi matematika dengan baik. Hal ini sejalan dengan pendapat Salirawati (2011) bahwa dalam memahami materi pokok kesetimbangan kimia yang di dalamnya terdapat prinsip-prinsip operasi matematika peserta didik seharusnya menguasai operasi matematika dengan baik agar tidak terjadi kesalahan pemahaman. Menurut Sidauruk (1995) kesulitan siswa disebabkan ketidakmampuan siswa memfungsikan atribut suatu konsep sehingga terjadi kesalahan dalam memahami konsep. Perlu diperhatikan oleh guru bahwa istilahistilah kimia, pengetahuan prasyarat, dan kemampuan operasi matematika siswa juga merupakan bagian dari anak tangga yang harus dilewati siswa dengan lancar agar dapat dengan mudah menuju konsep yang ingin dicapai. 


\section{KESIMPULAN}

Uraian yang dipaparkan pada pembahasan dapat dibuat kesimpulan yaitu penggunaan media video berbantuan LKPD dapat meningkatkan hasil belajar siswa yang ditunjukkan dari nilai siswa setelah mengikuti pembelajaran melampaui KKM yang telah ditetapkan oleh sekolah yaitu di atas 78 .

Saran berdasarkan hasil penelitian ini antara lain:

1. Guru saat melakukan pembelajaran menggunakan media video berbantuan LKPD agar lebih memperhatikan pengetahuan prasyarat siswa sehingga proses membangun konsep siswa saat pembelajaran menjadi lebih optimal dan tidak terkendala dengan pengetahuan prasyarat yang ternyata belum dipahami siswa.

2. Penyusunan media video berbantuan LKPD agar lebih memperhatikan kesesuaian antara waktu yang disediakan dengan kompleksitas materi yang ingin diajarkan, sehingga tidak ada lagi alasan dari siswa bahwa waktu yang disediakan kurang dalam memahami konsep yang dimaksud.

3. Pembelajaran dengan media video berbantuan LKPD dapat dilaksanakan pada semua konsep dalam mata pelajaran kimia, serta dapat juga digunakan untuk mata pelajaran lainnya.

\section{DAFTAR PUSTAKA}

Adawiyah, R., 2017, 'Deskripsi Kesalahan Konsep Siswa pada Materi Kesetimbangan Kimia di SMAN 1 Teluk Keramat', Jurnal Pendidikan dan Pembelajaran Khatulistiwa, vol. 6, no. 10, dilihat 1 September 2020, (https://jurnal.untan.ac.id/index.php/jpdpb/article/view/22594).

Erdemir, A., Geban, O. \& Uzuntiryaki, E., 2000, 'Freshman Students' Misconceptions in Chemical Equilibrium', Hacettepe Üniversitesi Ĕgitim Fakültesi Dergisi, vol. 18, hh. 79-84, dilihat 3 Mei 2021, https://dergipark.org.tr/tr/download/article-file/88006).

Indriani, A., Suryadharma, I. B., \& Yahmin, 2017, 'Identifikasi Kesulitan Peserta Didik dalam Memahami Kesetimbangan Kimia', Jurnal Pembelajaran Kimia Universitas Negeri Malang, vol. 2, no. 1, hh. 9-13, dilihat 1 September 2020, (http://journal2.um.ac.id/index.php/jpek/article/view/1973).

Majid, A. \& A.S. Firdaus., 2014, Penilaian Autentik (Proses dan Hasil Belajar), Interes Media, Bandung.

Monita, F.A. \& B. Suharto., 2016, 'Identifikasi dan Analisis Miskonsepsi Siswa Menggunakan Three-Tier Multiple Choice Diagnostic Instrument pada Konsep Kesetimbangan Kimia', Quantum : Jurnal Inovasi Pendidikan Sains, vol. 7, no. 1, hh. 27-38, dilihat 1 September 2020, (https://ppjp.ulm.ac.id/journal/index.php/quantum/article/view/3538). 
Nurhayati, S., Ifriani, A., \& Lestari, I., 2014, 'Pengaruh Video-Animasi terhadap Hasil Belajar Siswa Kelas XI SMAN 5 Pontianak pada Materi Kesetimbangan Kimia', Jurnal Pendidikan dan Pembelajaran Khatulistiwa, vol. 3, no. 6, dilihat 17 April 2021, (https://jurnal.untan.ac.id/index.php/jpdpb/article/view/6058).

Oktaria, S.F., 2012, Miskonsepsi Kesetimbangan Kimia Siswa SMA Kelas XI IPA di Kotawaringin Barat, Tesis Magister, Program Pasca Sarjana Universitas Palangka Raya, Palangka Raya.

Prastowo, A., 2014, Pengembangan Bahan Ajar Tematik, Tinjauan Teoretis dan Praktik, Penerbit Kencana (Prenadamedia Group), Jakarta.

Salirawati, D., 2011, 'Pengembangan Instrumen Pendeteksi Miskonsepsi Kesetimbangan Kimia pada Peserta Didik SMA', Jurnal Penelitian dan Evaluasi Pendidikan, vol. 15, no. 2, hh. 232-249, dilihat 3 Mei 2021, (https://journal.uny.ac.id/index.php/jpep/article/view/1095).

Sani, R.A., 2015, Pembelajaran Saintifik untuk Implementasi Kurikulum 2013, Bumi Aksara, Jakarta.

Sanjaya, W., 2012, Media Komunikasi Pembelajaran, Penerbit Kencana (Prenadamedia Group), Jakarta.

Sidauruk, S., 1995, Kesulitan Siswa SMA Memahami Konsep Kimia, Tesis Magister, Program Pasca Sarjana Institut Keguruan dan Ilmu Pendidikan Jakarta, Jakarta.

Suyanto \& Jihad, 2013, Menjadi Guru Profesional, Esensi-Erlangga Group, Jakarta.

Trianto, 2009, Mendesain Model Pembelajaran Inovatif-Progresif, Penerbit Kencana (Prenadamedia Group), Jakarta.

Trianto, 2011, Pengantar Penelitian Pendidikan bagi Pengembangan Profesi Pendidikan dan Tenaga Kependidikan. Penerbit Kencana (Prenadamedia Group), Jakarta.

Usu, N., R. Rahmanpiu \& M.A. Marhadi., 2019, 'Analisis Miskonsepsi Siswa Pada Materi Kesetimbangan Kimia Menggunakan Tes Diagnostik Two Tier Multiple Choice', Jurnal Pendidikan Kimia FKIP Universitas Halu Oleo, vol. 4, no.3, ISSN : 2503-4480, dilihat 1 September 2020, (http://ojs.uho.ac.id/index.php/jpkim/article/view/11738).

Virtayanti, I. A., Abudarin \& Wijayanti, E., 2019, 'Pengaruh Lembar Kerja Siswa Berorientasi Keterampilan Generik Sains dengan Model Pembelajaran Discovery Learning terhadap Pemahaman Konsep Kesetimbangan Kimia', Jurnal Kependidikan, Pembelajaran dan Pengembangan, vol. 01, no. 01, hh. 17-23, dilihat 17 April 2021, (https://ejournal.billfath.ac.id/index.php/karangan/article/view/3).

Yaumi, M., 2018, Media dan Teknologi Pembelajaran, Penerbit Kencana (Prenadamedia Group), Jakarta. 